\title{
Associations between VDR gene polymorphisms and colorectal cancer susceptibility: an updated meta-analysis based on 39 case-control studies
}

\author{
Zhipeng Pan ${ }^{1, *}$, Mengya Chen ${ }^{2,3, *}$, Xingxing Hu ${ }^{2,3}$, Hua Wang ${ }^{1}$, Jiajia Yang ${ }^{2,3}$, Congjun \\ Zhang ${ }^{1}$, Faming Pan $^{2,3}$ and Guoping Sun ${ }^{1}$ \\ ${ }^{1}$ Department of Medical Oncology, The First Affiliated Hospital of Anhui Medical University, Hefei, Anhui, 230032, China \\ ${ }^{2}$ Department of Epidemiology and Biostatistics, School of Public Health, Anhui Medical University, Hefei, Anhui, 230032, China \\ ${ }^{3}$ The Key Laboratory of Major Autoimmune Diseases, Anhui Medical University, Hefei, Anhui, 230032, China \\ *These authors contributed equally to this work and should be considered co-first authors \\ Correspondence to: Guoping Sun, email: sunguoping@ ahmu.edu.cn \\ Faming Pan, email: famingpan@ahmu.edu.cn
}

Keywords: vitamin D receptor; colorectal cancer; VDR; meta-analysis; polymorphisms

Received: July 26, 2017 Accepted: November 14, $2017 \quad$ Published: January 04, 2018

Copyright: Pan et al. This is an open-access article distributed under the terms of the Creative Commons Attribution License 3.0 (CC BY 3.0), which permits unrestricted use, distribution, and reproduction in any medium, provided the original author and source are credited.

\section{ABSTRACT}

Background: Recent studies have reported the associations between vitamin D receptor (VDR) polymorphisms and colorectal cancer (CRC), but the results were not always consistent. This meta-analysis aims to evaluate whether VDR polymorphisms are associated with CRC susceptibility.

Materials And Methods: Studies on the associations between VDR polymorphisms and CRC were retrieved from the Web of Science, PubMed, the Chinese Biomedical Database (CBM), Chinese National Knowledge Infrastructure (CNKI) and Wanfang (Chinese) databases. The odds ratio (OR) with $95 \%$ confidence intervals (CIs) was obtained.

Results: Thirty-nine articles met all inclusion criteria and were included in the meta-analysis including 22101 CRC cases and 23696 healthy controls. The 39 articles consisted of five VDR gene polymorphisms including ApaI, FokI, BsmI, TaqI and Cdx2. The results of meta-analysis showed that the FokI polymorphism was on the fringe of statistically significant in the comparisons of $F$ allele vs. $f$ allele in fixed model $(O R=$ $1.029,95 \% \mathrm{CI}=0.999-1.059, \mathrm{P}_{\mathrm{raw}}=0.057, \mathrm{P}_{\mathrm{FDR}}=0.057$ ). Moreover, for the associations between BsmI polymorphism with CRC, We observed significant differences in allele frequencies, the homozygous model and the dominant model between CRC patients and healthy controls ( $B$ vs. $b$ : $O R=0.862,95 \% \mathrm{CI}=0.761-0.976, \mathrm{P}_{\text {raw }}=0.019, \mathrm{P}_{\mathrm{FDR}}=$ 0.019; BB vs. bb: $\mathrm{OR}=0.786,95 \% \mathrm{CI}=0.636-0.972, \mathrm{Praw}=0.026, \mathrm{P}_{\mathrm{FDR}}=0.039 ; \mathrm{BB}+$ Bb vs. bb: $O R=0.934,95 \% C I=0.888-0.982$, Praw $=0.008, P_{F D R}=0.024$, respectively).

Conclusions: This meta-analysis suggests that BsmI is associated with CRC risk and FokI might be a risk factor for CRC. However, these associations with CRC need further studied.

\section{INTRODUCTION}

Colorectal cancer (CRC) is a major health problem and is currently ranked third for both cancer incidence and mortality [1]. In spite of the revised treatment patterns, CRC remains a major cause of cancer mortality. At an estimated 1.2 million new cancer cases and 608,700 deaths worldwide each year, people who die from CRC account for $8 \%$ of all cancer related deaths [2]. The incidence rate of CRC has been increasing greatly in China in the past few years, which accounts for about $6.5 \%$ of total cancers in urban areas and $4.6 \%$ in rural areas [3]. CRC is a multifactorial disease, involving the complex interactions between environmental and genetic factors [4]. However, the exact mechanisms which result in the development of colorectal cancer remain unclear. Nowadays, a large 
number of candidate genes responsible for the genesis of colorectal cancer have been identified.

Recently, the associations between vitamin D and colorectal cancer has aroused a great deal of attention, and genetic variation in metabolic pathways for these nutrients may play a role in colorectal carcinogenesis [5]. It's known to us that Vitamin D plays an important role in calcium absorption, cellular proliferation and differentiation, as well as carcinogenesis. Animal studies and case-control studies in humans have provided strong evidence that vitamin D protects against colorectal cancer $[6,7]$. Genomic actions of the active metabolite of vitamin $\mathrm{D}\left[1,25(\mathrm{OH})_{2} \mathrm{D}_{3}\right]$ are mediated by the vitamin $\mathrm{D}$ receptor (VDR) which maps to a region on chromosome $12[8,9]$. The active form of vitamin $\mathrm{D}\left[1,25(\mathrm{OH})_{2} \mathrm{D}_{3}\right]$ is bound by the intracellular $V D R$. This complex bindings and interactions with target-cell nuclei (at $V D R$ elements) produce varieties of biological effects [10]. Recently, the VDR gene polymorphisms [11-49] including FokI $[12,13,15,18,19,21-26,29-32,35-39,41-43,45-47$, 49], BsmI [11-13, 15-18, 20, 23, 26, 27, 29, 30, 32, 33, 36, 37, 40-42, 44, 48, 49], ApaI [11-13, 15, 16, 18, 23, 27, 28, 30, 36, 41], TaqI [12-15, 17, 18, 20-24, 27, 28, $31,36,38,41,49]$ and $C d x 2$ [21, 30, 31, 36] have been assessed in genetic associations studies of CRC, but the results from these studies are still inconsistent. Three meta-analyses $[3,50,51]$ had been published assessing the associations between $V D R$ polymorphisms and CRC risk in recent years. However, there are some limitations in the three studies, such as relatively small sample size. Moreover, a number of studies that assessed the associations between $V D R$ polymorphisms and CRC risk were published after that period. In order to derive a more comprehensive estimation of the associations between $V D R$ polymorphisms and CRC risk, we conducted a metaanalysis from 39 eligible case-control studies to evaluate the associations.

\section{RESULTS}

\section{Data source}

Figure 1 summarizes the selection process of study. According to the strategy, 139 published studies relevant to the $V D R$ genes and the risk of CRC were reviewed including 28 from The Web of Science; 96 from PubMed; five from CBM and 10 from CNKI. 52 articles were selected for full-text review on the basis of their titles and abstracts. Finally, 39 articles met all inclusion criteria and were included in the meta-analysis including 22101 CRC cases and 23696 healthy controls. The 39 articles [11-49] consisted of five VDR gene polymorphisms including FokI $[12,13,15,18,19,21-26,29-32,34-39,41-43,45-47$, 49], BsmI [11-13, 15-18, 20, 23, 26, 27, 29, 30, 32, 33, 36, 37, 40-42, 44, 48, 49], ApaI [11-13, 15, 16, 18, 23, 27, 28, 30, 36, 41], TaqI [12-15, 17, 18, 20-24, 27, 28, 31, 36, 38,
41, 49] and $C d x 2$ [21, 30, 31, 36]. Selected characteristics on the relationships between $V D R$ polymorphisms and CRC were listed in Table 1.

\section{Heterogeneity and publication bias}

The heterogeneity was assessed for each study using the $Q$ statistic. Significant heterogeneity ( $P$ for heterogeneity $<0.10$ or $I^{2}>50 \%$ ) between studies were observed in BsmI and ApaI, but no heterogeneity was found in FokI, TaqI and Cdx2 polymorphisms.

Funnel plot and Egger's test were performed to evaluate the publication bias of literatures on CRC, and no statistically significant publication biases were found in all genetic models.

\section{Meta-analysis results}

\section{FokI polymorphism and CRC}

A total of 29 studies examined the association between CRC and the FokI polymorphism. The result of meta-analysis showed that the FokI polymorphism was on the fringe of statistically significant in the comparison of $\mathrm{F}$ allele vs. $\mathrm{f}$ allele in fixed model $(\mathrm{OR}=1.029$, $\left.95 \% C I=0.999-1.059, P^{\text {raw }}=0.057, P_{F D R}=0.057\right)$. The homozygous model, the dominant model and the recessive model were no significant associated with CRC risk (Table 2).

\section{BsmI polymorphism and CRC}

There were 23 articles on the relationship between BsmI polymorphism and CRC. We observed significant differences in allele frequencies, the homozygous model and the dominant model between CRC patients and healthy controls (B vs. b: $\mathrm{OR}=0.862,95 \% \mathrm{CI}=0.761-$ $0.976, P_{\text {raw }}=0.019, P_{\mathrm{FDR}}=0.019 ; \mathrm{BB}$ vs. bb: $\mathrm{OR}=0.786$, $95 \% C I=0.636-0.972, P_{\text {raw }}=0.026, \mathrm{P}_{F D R}=0.039 ; \mathrm{BB}$ + Bb vs. bb: $\mathrm{OR}=0.824,95 \% C I=0.705-0.964, P_{\text {raw }}$ $=0.015, P_{\mathrm{FDR}}=0.039$, respectively). There was little evidence of significant differences that investigated an association between BsmI polymorphism and CRC in the recessive model (Table 2, Figure 2).

\section{Other polymorphisms and CRC}

Other three polymorphisms including ApaI, TaqI, $C d x 2$ were not associated with $\mathrm{CRC}$ in all genetic models.

\section{Sensitivity analysis}

Sensitivity analysis was performed by sequential omission of individual studies. The pooled ORs of the polymorphisms were not altered after omission, indicating that our results were statistically robust. 
Table 1: Characteristics of individual studies included in meta-analysis

\begin{tabular}{|c|c|c|c|c|c|c|c|c|c|}
\hline \multirow{2}{*}{ First Author } & \multirow{2}{*}{ Year } & \multirow{2}{*}{ Country } & \multirow{2}{*}{ Ethnicity } & \multirow{2}{*}{$\frac{\text { Case/ Control }}{N}$} & \multicolumn{2}{|c|}{ age } & \multirow{2}{*}{$\begin{array}{c}\text { Control } \\
\text { Methods }\end{array}$} & \multirow{2}{*}{ HWE } & \multirow{2}{*}{ VDR polymorphisms } \\
\hline & & & & & case & control & & & \\
\hline Vigidal [11] & 2016 & Brazil & Caucasian & $152 / 321$ & $62.8 \pm 13.02$ & $62.7 \pm 10.42$ & PCR-RFLP & Yes & BsmI, AapI \\
\hline Alkhayal [12] & 2016 & Saudi Arabia & Caucasian & $100 / 100$ & $57.5(20-80)$ & $57.5(21-81)$ & PCR & No & FokI, BsmI, AapI, TaqI \\
\hline Takeshige [13] & 2015 & Japan & Asian & $685 / 778$ & $60.2 \pm 9.1$ & $58.6 \pm 10.7$ & PCR-RFLP & Yes & FokI, BsmI, AapI, TaqI \\
\hline Atoum [14] & 2014 & Jordan & Asian & $93 / 102$ & NA & NA & PCR & Yes & TaqI \\
\hline Laczmanska [15] & 2014 & Poland & Caucasian & $179 / 180$ & $65.7(32-87)$ & NA & PCR & No & FokI, BsmI, AapI, TaqI \\
\hline Rasool [16] & 2014 & India & Asian & $180 / 188$ & 52.05 & 51.06 & PCR-RFLP & No & BsmI, AapI \\
\hline Pibiri [17] & 2014 & United States & $\begin{array}{c}\text { African } \\
\text { American }\end{array}$ & $961 / 838$ & $62.0 \pm 10$ & $65.0 \pm 6$ & PCR & Yes & BsmI, TaqI \\
\hline Sarkissyan [18] & 2014 & American & Mixed & $78 / 230$ & $55.2 \pm 9.9$ & $54.9 \pm 9.8$ & PCR-RFLP & Yes & FokI, BsmI, AapI, TaqI \\
\hline Rasool [19] & 2013 & India & Asian & $312 / 305$ & 52.05 & 51.06 & PCR & Yes & FokI \\
\hline Gunduz [20] & 2012 & Turkey & Caucasian & $43 / 42$ & 54.8 & 48.8 & PCR-RFLP & No & BsmI, TaqI \\
\hline Bentley [21] & 2102 & New Zealand & Asian & $200 / 200$ & $69.5 \pm 0.4$ & $69.5 \pm 0.4$ & Taqman & Yes & FokI, TaqI, Cdx2 \\
\hline Yamaji [22] & 2012 & Japan & Asian & $684 / 641$ & NA & NA & Taqman & Yes & FokI, TaqI \\
\hline Kupfer [23] & 2011 & United States & Mixed & $2119 / 1975$ & $64.5 \pm 11.7$ & $62.3 \pm 13.2$ & Taqman & Yes & FokI, BsmI, AapI, TaqI \\
\hline Ashktorab [24] & 2011 & United States & Caucasian & $93 / 187$ & 59 & 60 & PCR & Yes & FokI, TaqI \\
\hline Abulí [25] & 2011 & Spain & Caucasian & $515 / 515$ & NA & NA & Taqman & Yes & FokI \\
\hline Mahmoudi [26] & 2010 & Iran & Asian & $452 / 452$ & $44.3 \pm 17.2$ & $53.7 \pm 13.3$ & PCR-RFLP & Yes & FokI, BsmI \\
\hline Hughes [27] & 2010 & $\begin{array}{c}\text { Czech } \\
\text { Republic }\end{array}$ & Caucasian & $754 / 627$ & $61(27-85)$ & $53(29-91)$ & ASM-PCR & Yes & BsmI, AapI, TaqI \\
\hline Mahmoudi [28] & 2010 & Iran & Asian & $160 / 180$ & $52.6 \pm 14.0$ & $44.4 \pm 17.6$ & PCR-RFLP & No & AapI, TaqI \\
\hline Jenab [29] & 2009 & $\begin{array}{l}\text { United } \\
\text { Kingdom }\end{array}$ & Caucasian & $1248 / 1248$ & $58.5 \pm 7.2$ & $58.6 \pm 7.2$ & Taqman & Yes & FokI, BsmI \\
\hline Theodoratou [30] & 2008 & $\begin{array}{c}\text { United } \\
\text { Kingdom }\end{array}$ & Caucasian & $3005 / 3072$ & $62.0 \pm 10.7$ & $62.4 \pm 10.5$ & Microarray & No & FokI, BsmI, AapI, Cdx2 \\
\hline Ochs-Balcom [31] & 2008 & United States & Mixed & $250 / 246$ & $62.7 \pm 10.2$ & $58.4 \pm 12.1$ & Taqman & Yes & FokI, TaqI, Cdx2 \\
\hline $\operatorname{Li}[32]$ & 2008 & China & Asian & $200 / 200$ & $61.5 \pm 12.6$ & $61.3 \pm 12.5$ & PCR-RFLP & Yes & FokI, BsmI \\
\hline Parisi [33] & 2008 & Spain & Caucasian & $50 / 32$ & NA & NA & PCR-RFLP & Yes & BsmI \\
\hline Wang [34] & 2008 & China & Asian & $60 / 218$ & $38-78$ & $19.6 \pm 1.3$ & PCR-RFLP & Yes & FokI \\
\hline Grünhage [35] & 2008 & Germany & Caucasian & $194 / 220$ & $65 \pm 9$ & $63 \pm 8$ & PCR-RFLP & Yes & FokI \\
\hline Flügge [36] & 2007 & Germany & Caucasian & $256 / 256$ & $61.9 \pm 10.0$ & $62.2 \pm 11.2$ & PCR-RFLP & Yes & FokI, BsmI, AapI, TaqI, Cdx2 \\
\hline Slattery [37] & 2007 & United States & Caucasian & $2380 / 2990$ & NA & NA & Taqman & Yes & FokI, BsmI \\
\hline Yaylim-Eraltan [38] & 2007 & Turkey & Caucasian & $26 / 52$ & $59.1 \pm 4.0$ & $52.0 \pm 0.8$ & PCR-RFLP & No & FokI, TaqI \\
\hline Murtaugh [39] & 2006 & United States & Caucasian & $1820 / 2821$ & NA & NA & PCR-RFLP & Yes & FokI \\
\hline Kadiyska [40] & 2006 & Bulgaria & Caucasian & $140 / 94$ & $59(22-83)$ & NA & PCR-RFLP & Yes & BsmI \\
\hline Park [41] & 2006 & South Korea & Asian & $190 / 318$ & $55(32-81)$ & NA & PCR-RFLP & Yes & FokI, BsmI, AapI, TaqI \\
\hline Slattery [42] & 2004 & United States & Caucasian & $1936 / 2130$ & NA & NA & PCR-RFLP & No & FokI, BsmI \\
\hline Peters [43] & 2004 & United States & Caucasian & $763 / 774$ & 62.9 & 62.3 & PCR-RFLP & Yes & FokI \\
\hline Boyapati [44] & 2003 & United States & Caucasian & $177 / 228$ & $58.4 \pm 8.4$ & $56.0 \pm 10.0$ & PCR-RFLP & No & BsmI \\
\hline Wong [45] & 2003 & China & Asian & $217 / 890$ & 56.5 & NA & PCR-RFLP & Yes & FokI \\
\hline Peters [46] & 2001 & United States & Caucasian & $239 / 228$ & NA & NA & PCR-RFLP & Yes & FokI \\
\hline Ingles [47] & 2001 & United States & Caucasian & $373 / 394$ & 62.3 & 62.2 & PCR-RFLP & Yes & FokI \\
\hline Kim [48] & 2001 & United States & Caucasian & $393 / 406$ & $57.9 \pm 9.7$ & $53.0 \pm 10.9$ & Taqman & Yes & BsmI \\
\hline Slattery [49] & 2001 & United States & Caucasian & $424 / 266$ & NA & NA & PCR-RFLP & Yes & FokI, BsmI, TaqI \\
\hline
\end{tabular}

VDR, vitamin D receptor; PCR, polymerase chain reaction; PCR-RFLP, polymerase chain reaction-restriction fragment length polymorphism; ASM-PCR, allele specific multiple-PCR; HWE, Hardy-Weinberg equilibrium; NA, Not available.

\section{DISCUSSION}

The pathogenesis of CRC remains unknown. Geneenvironment interactions, gene-gene interactions and life-style have an important impact on the development of CRC. There is consistent epidemiologic evidence that increased vitamin D intake is associated with reduced risk of colorectal. $V D R$ mediate the biological activity of vitamin D and plays a crucial role in the etiology and development of cancer. A number of genetic associations studies were carried out to investigate the association of $V D R$ polymorphisms with CRC risk, but the results are conflictive and the effect of $V D R$ polymorphisms on $\mathrm{CRC}$ remains unclear. Therefore, in order to overcome the limitations of individual studies, we performed meta-analysis to evaluate the associations 
of $V D R$ polymorphisms with CRC risk. Meta-analysis increases statistical power and resolution by pooling the results of independent analyses. A total of 52 reports had predicted a potential genetic association, and only 39 articles were included in this meta-analysis based on the selection criteria. The meta-analysis showed that the FokI polymorphism was on the fringe of statistically significant in the comparisons of $\mathrm{F}$ vs. $\mathrm{f}(\mathrm{OR}=1.029,95 \% \mathrm{CI}=$ 0.999-1.059, $\left.P_{\text {raw }}=0.057, P_{F D R}=0.057\right)$ and the $B s m I$ $B$ allele was associated with a lower CRC risk (B vs. b: $\mathrm{OR}=0.862$, 95\% $C I=0.761-0.976, P_{\text {raw }}=0.019, P_{F D R}=$ 0.019). Similarly, a decreased CRC risk was also found in the homozygous model and the dominant model of BsmI (BB vs. bb: $\mathrm{OR}=0.786,95 \% C I=0.636-0.972, P_{\text {raw }}=$ $0.026, P_{F D R}=0.039 ; \mathrm{BB}+\mathrm{Bb}$ vs. bb: $\mathrm{OR}=0.824,95 \% C I$ $=0.705-0.964, P_{\text {raw }}=0.015, P_{F D R}=0.039$, respectively). The results are consistent with the previous meta-analysis, which further confirmed the conclusions of the previous meta-analysis. However, our results were not consistent with the previous meta-analysis in the recessive model of BsmI and CRC. Yu et al. [3] and Bai et al. [51] draw the conclusion that the recessive model of BsmI was associated with a decreased CRC risk. The reasons for different results are as follows: first, our study is an updated and more carefully selected study than Yu et al and Bai et al. Second, our study included more Asian population. The estimated VDR polymorphisms including FokI, ApaI, TaqI and $C d x 2$ showed no significant associations between CRC. Previous meta-analysis's pooled ORs were similar to ours. In addition, we found significant heterogeneities between studies in BsmI and ApaI. But the reasons for the heterogeneity were unclear. The heterogeneity may be explained by the following factors: the study design, clinical characteristics, year of publication, and especially the different genetic backgrounds.

As in any study, some limitations of this study should be considered. First, only published studies in English and Chinese were included in this meta-analysis, so publication bias may have occurred. Second, significant heterogeneity was observed in overall comparisons. Although no publication bias was observed, different background and variant adjusted factors of controls were possible major source of heterogeneity. Third, although environment and diet may partially contribute to $\mathrm{CRC}$, gene-gene and gene-environment interactions could not be investigated. Fourth, meta-analysis was still an observational study that subjected to the methodological deficiencies of the included studies.

In conclusion, this meta-analysis suggests that BsmI was associated with CRC risk and FokI might be risk factors for CRC. However, these associations with CRC need further studied.

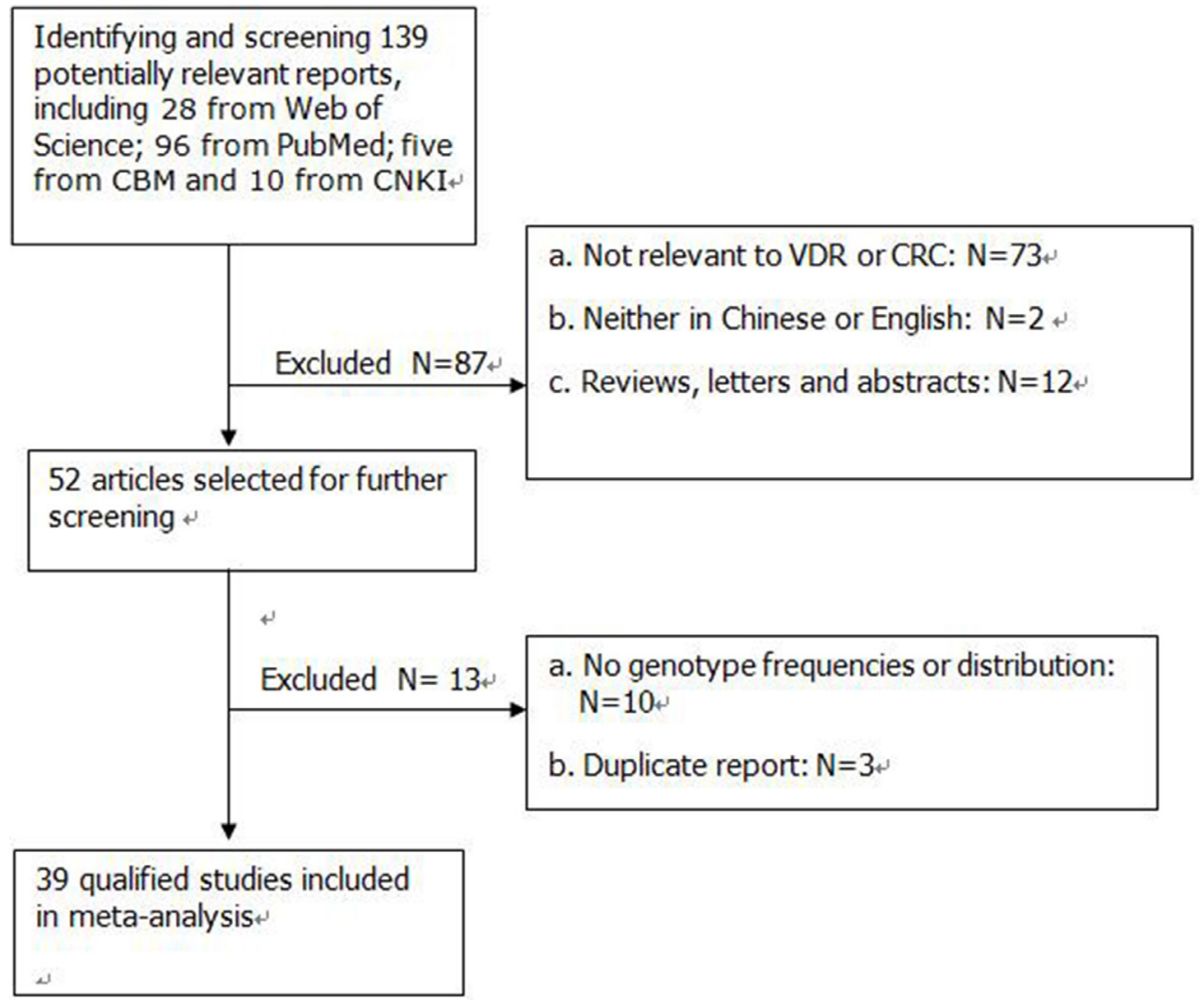

Figure 1: Flow diagram of the study selection process. 
Table 2: Meta-analysis of the association between VDR polymorphisms and CRC

\begin{tabular}{|c|c|c|c|c|c|c|c|}
\hline SNP & Comparison & $\begin{array}{c}\text { Qualified } \\
\text { studies }\end{array}$ & OR $(95 \% C I)$ & $P$-value & FDR & Heterogeneity test & $\begin{array}{l}\text { Effect } \\
\text { model }\end{array}$ \\
\hline \multirow[t]{4}{*}{ FokI } & F vs. f & 29 & $1.029(0.999-1.059)$ & 0.057 & 0.057 & $P=0.003, \mathrm{I}^{2}=46.8 \%$ & $\mathrm{~F}$ \\
\hline & FF vs. ff & & $1.055(0.990-1.123)$ & 0.097 & 0.211 & $P=0.015, \mathrm{I}^{2}=39.8 \%$ & $\mathrm{~F}$ \\
\hline & $\mathrm{FF}+\mathrm{Ff}$ vs. ff & & $1.045(0.986-1.107)$ & 0.141 & 0.211 & $P=0.124, \mathrm{I}^{2}=23.9 \%$ & $\mathrm{~F}$ \\
\hline & $\mathrm{Ff}+\mathrm{ff} v \mathrm{vs} . \mathrm{FF}$ & & $0.974(0.876-1.083)$ & 0.625 & 0.625 & $P<0.001, \mathrm{I}^{2}=81.5 \%$ & $\mathrm{R}$ \\
\hline \multirow[t]{4}{*}{ BsmI } & B vs. $b$ & 23 & $0.862(0.761-0.976)$ & $0.019^{*}$ & $0.019^{*}$ & $P<0.001, \mathrm{I}^{2}=91.4 \%$ & $\mathrm{R}$ \\
\hline & BB vs.bb & & $0.786(0.636-0.972)$ & $0.026^{*}$ & $0.039^{*}$ & $P<0.001, \mathrm{I}^{2}=85.5 \%$ & $\mathrm{R}$ \\
\hline & $\mathrm{BB}+\mathrm{Bb}$ vs. bb & & $0.824(0.705-0.964)$ & $0.015^{*}$ & $0.039^{*}$ & $P<0.001, \mathrm{I}^{2}=88.0 \%$ & $\mathrm{R}$ \\
\hline & $\mathrm{Bb}+\mathrm{bb}$ vs. $\mathrm{BB}$ & & $0.887(0.759-1.036)$ & 0.129 & 0.129 & $P<0.001, \mathrm{I}^{2}=78.8 \%$ & $\mathrm{R}$ \\
\hline \multirow[t]{4}{*}{ ApaI } & A vs. a & 12 & $1.025(0.928-1.132)$ & 0.631 & 0.631 & $P<0.001, \mathrm{I}^{2}=68.9 \%$ & $\mathrm{R}$ \\
\hline & AA vs. aa & & $0.953(0.775-1.172)$ & 0.650 & 0.900 & $P<0.001, \mathrm{I}^{2}=67.9 \%$ & $\mathrm{R}$ \\
\hline & $\mathrm{AA}+\mathrm{Aa}$ vs. aa & & $1.009(0.875-1.163)$ & 0.900 & 0.900 & $P=0.003, \mathrm{I}^{2}=59.8 \%$ & $\mathrm{R}$ \\
\hline & $\mathrm{Aa}+\mathrm{aa}$ vs. AA & & $0.901(0.770-1.055)$ & 0.197 & 0.591 & $P=0.001, \mathrm{I}^{2}=65.5 \%$ & $\mathrm{R}$ \\
\hline \multirow[t]{4}{*}{ TaqI } & T vs. $t$ & 18 & $1.011(0.960-1.066)$ & 0.673 & 0.673 & $P=0.081, \mathrm{I}^{2}=33.1 \%$ & $\mathrm{~F}$ \\
\hline & TT vs. tt & & $1.027(0.912-1.157)$ & 0.656 & 0.746 & $P=0.091, \mathrm{I}^{2}=32.5 \%$ & $\mathrm{~F}$ \\
\hline & $\mathrm{TT}+\mathrm{Tt}$ vs. tt & & $1.018(0.913-1.136)$ & 0.746 & 0.746 & $P=0.069, \mathrm{I}^{2}=35.4 \%$ & $\mathrm{~F}$ \\
\hline & $\mathrm{Tt}+\mathrm{tt}$ vs. TT & & $1.013(0.944-1.086)$ & 0.724 & 0.746 & $P=0.310, \mathrm{I}^{2}=11.8 \%$ & $\mathrm{~F}$ \\
\hline \multirow[t]{4}{*}{$\mathrm{Cdx} 2$} & C vs. c & 4 & $0.936(0.828-1.058)$ & 0.287 & 0.287 & $P=0.352, \mathrm{I}^{2}=8.2 \%$ & $\mathrm{~F}$ \\
\hline & $\mathrm{CC}$ vs. cc & & $0.862(0.627-1.186)$ & 0.363 & 0.544 & $P=0.193, \mathrm{I}^{2}=36.6 \%$ & $\mathrm{~F}$ \\
\hline & $\mathrm{CC}+\mathrm{Cc}$ vs. cc & & $0.933(0.723-1.204)$ & 0.594 & 0.594 & $P=0.176, \mathrm{I}^{2}=39.3 \%$ & $\mathrm{~F}$ \\
\hline & $\mathrm{Cc}+\mathrm{cc}$ vs. CC & & $0.918(0.783-1.077)$ & 0.293 & 0.544 & $P=0.777, \mathrm{I}^{2}=0.0 \%$ & $\mathrm{~F}$ \\
\hline
\end{tabular}

VDR, vitamin D receptor; CRC, Colorectal cancer; OR, odds ratios; $95 \%$ CI, 95\% confidence interval; FDR: $p$ value from Benjamini-Hochberg method control for false discovery rate (FDR); R, random-effects model; F, fixed-effects model; "statistical significance.

\section{MATERIALS AND METHODS}

\section{Literature search strategy}

All genetic association studies that assessed the associations of the FokI, BsmI, ApaI, TaqI and Cdx2 polymorphisms in the $V D R$ genes with CRC susceptibility were included/enrolled in the meta-analysis. The studies were identified by extended computer based search of The PubMed, Web of Science, the Chinese Biomedical Database (CBM) and Chinese National Knowledge Infrastructure (CNKI) and Wanfang (Chinese) databases (published until April 2017). The keywords "Colorectal cancer" or "CRC" or "Colorectal carcinoma" or "Colorectal tumor", "polymorphism" or "variant" or "genes" or "genotypes" or "genotyping", "vitamin D receptor" or "VDR" were used. All references cited in the publications were also reviewed to identify other relevant publications. Finally, only published studies with full text were included.

\section{Inclusion and exclusion criteria}

Regarding CRC susceptibility and VDR gene polymorphisms, studies which satisfy all the following criteria were identified: (1) articles investigate the associations of the FokI, BsmI, ApaI, TaqI and Cdx2 polymorphisms in the VDR genes with the development of CRC; (2) a case-control study; (3) articles reported the number of individual genotypes and/or alleles for $V D R$ polymorphisms in cases and controls; (4) the paper should clearly describe CRC diagnoses; (5) the control' ethnic background and geographic area were the same with case'; (6) the language of articles was restricted to English or Chinese; (7) full text was available. Exclusion criteria: (1) the study was conducted on animals; (2) abstracts, case reports, editorials and review articles were excluded; (3) studies that did not met the inclusion criteria; (4) study with no detailed data.

\section{Data extraction}

According to the selection criteria, data from relevant studies were carefully and independently extracted by two authors (Zhipeng Pan and Mengya Chen). Disagreement was resolved by discussion and consultation with the third researcher (Xingxing $\mathrm{Hu}$ ). The following data were extracted if available: first author, year of publication, country, ethnicity of study population, the genotyping method, sample size, number of each genotype in cases and controls.

\section{Statistical analysis}

The strength of the associations between the $V D R$ polymorphisms and CRC susceptibility were 
evaluated by Odds ratios (ORs) with 95\% confidence intervals $(95 \%$ CIs $)$ under the appropriate genetic model. The pooled ORs were calculated for the allele contrasts, homozygous model, recessive genetic model and dominant genetic model. $P$ value $<0.05$ was considered to be statistically significant comparing CRC cases with controls. Considering the possibility of heterogeneity in the studies, heterogeneity assumption was measured by the chi-square based $Q$ test $(P<$ 0.1 indicates heterogeneity) [52]. In addition, the presence of heterogeneity between studies was tested by the $I^{2} . I^{2}$ values of 25,50 , and $75 \%$ are defined as low, moderate, and high estimates, respectively. The pooled effect was calculated by a fixed effect model when there is no heterogeneity $\left(I^{2}<50 \%\right.$ or $\left.P>0.1\right)$,

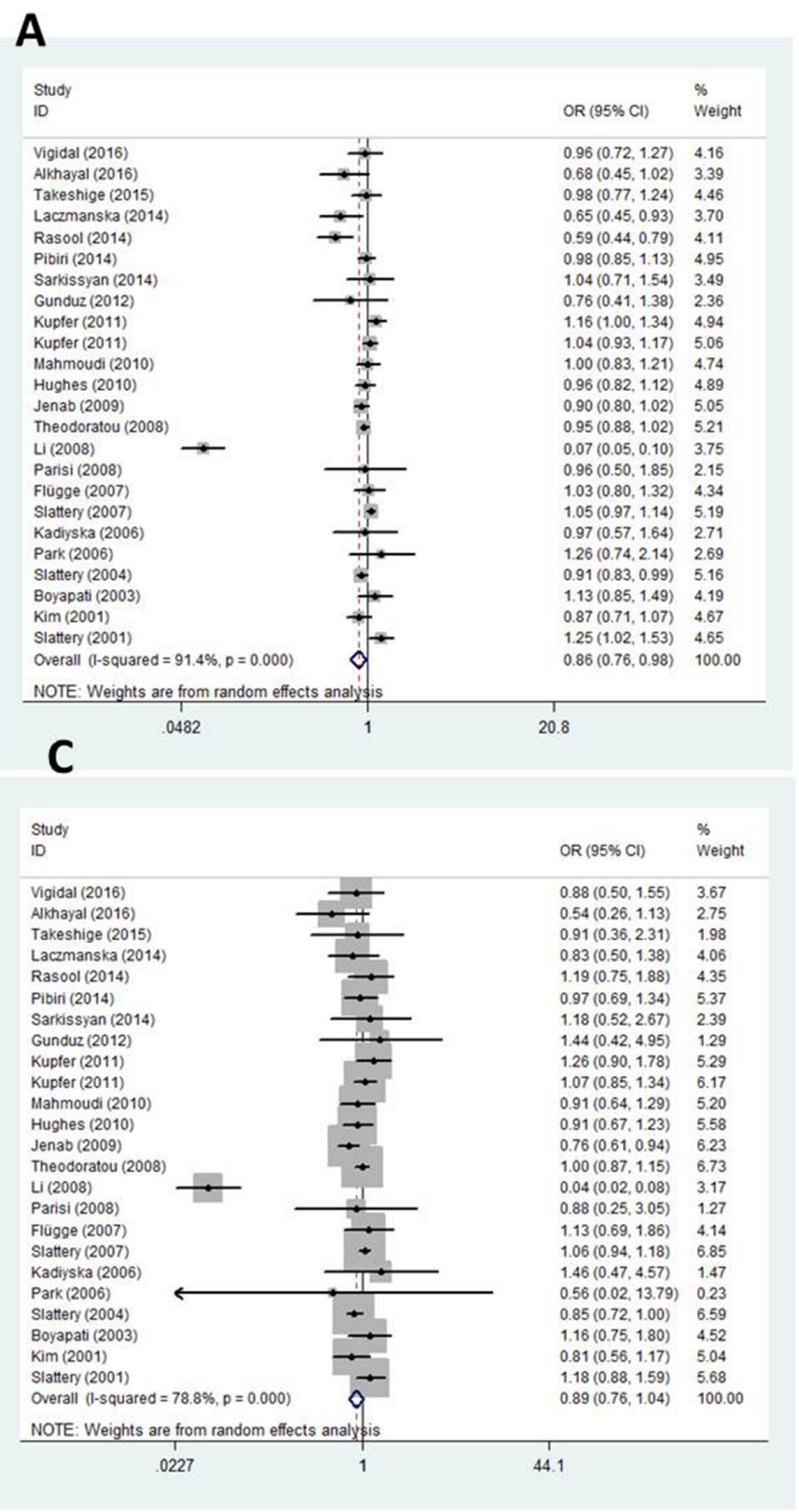

otherwise, a random effects model was used. HWE was assessed by the Chi-square test in the control group of each study in all the included studies $(P<$ 0.05 was considered significant). The funnel plot and Egger's regression test were used to search for publication bias, and an asymmetric Funnel plot or $P<0.05$ in Egger weighted regression suggested possible publication bias. In consideration of multiple comparisons, Benjamini-Hochberg $(\mathrm{BH})$ method was applied to control the false discovery rate (FDR). All the statistical manipulations were performed using the STATA statistical software 11.0 (StataCorp, College Station, TX, USA) and Review Manager Software 5.1 (Cochrane Collaboration, Oxford, UK). All $P$ values tested were two-tailed.
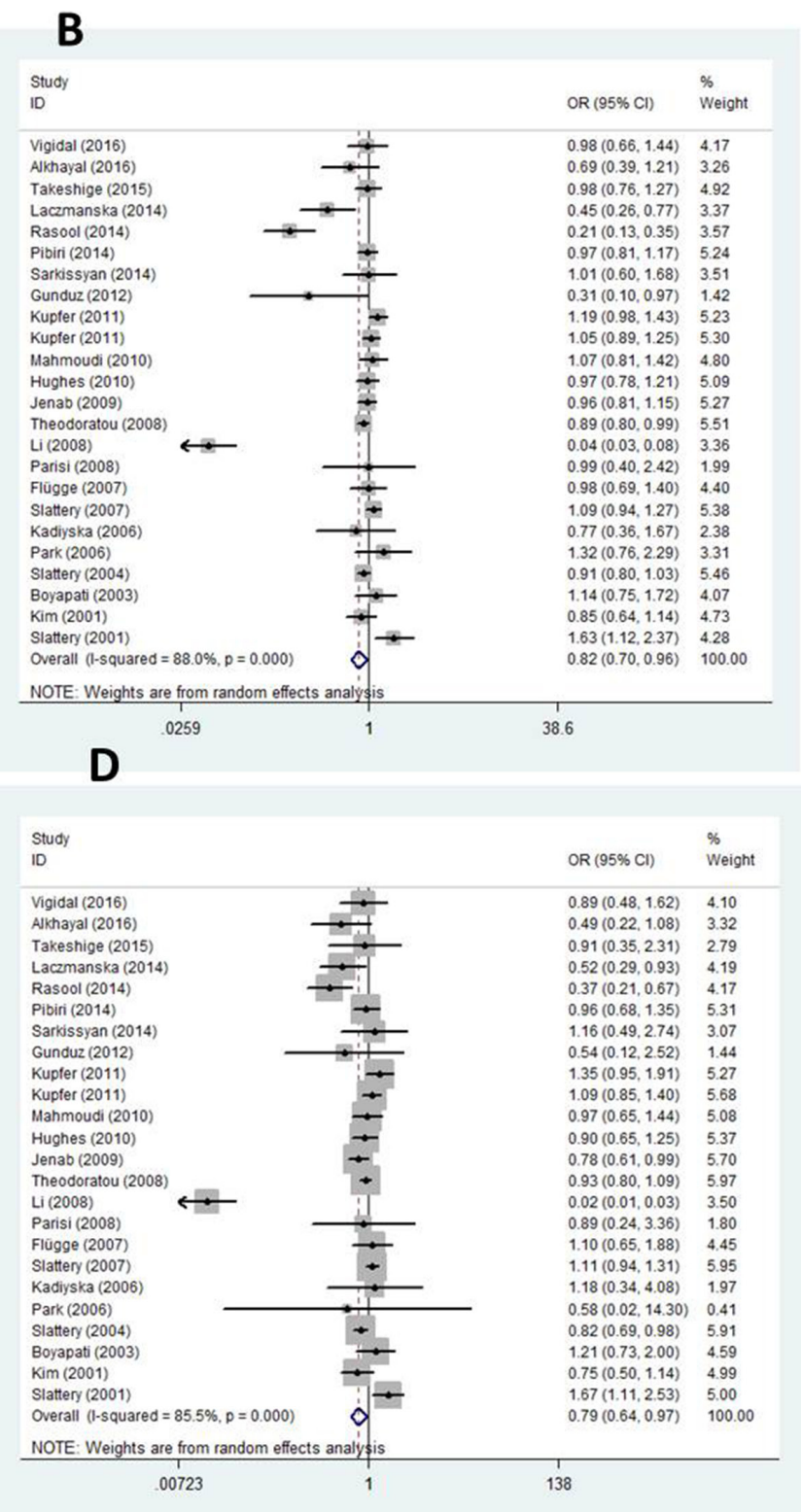

Figure 2: Forest plots for BsmI gene polymorphism and CRC. (A) Allelic mode (B) Dominant mode (C) Recessive model (D) Homozygous model. 


\section{Abbreviations}

CRC: Colorectal cancer; VDR: vitamin D receptor; CBM: the Chinese Biomedical Database; CNKI: Chinese National Knowledge Infrastructure; OR: odds ratio; 95\% CIs: 95\% confidence intervals; FDR: false discovery rate.

\section{Author contributions}

ZPP: Search the literature, Data extraction, Manuscript writing. MYC: Data extraction. XXH: Search the literature. JJY: Search the literature. HW: Software analysis. CJZ: Software analysis. FMP: Review the manuscript. GPS: Review the manuscript.

\section{ACKNOWLEDGMENTS}

Thanks for the people who participated in this study.

\section{CONFLICTS OF INTEREST}

All the authors declare that they have no conflicts of interest.

\section{FUNDING}

The study was supported by grants from the National Natural Science Foundation of China (30771849, 30972530, 81273169, 81573218 and 81773514).

\section{REFERENCES}

1. Süren D, Yıldırım M, Demirpençe Ö, Kaya V, Alikanoğlu AS, Bülbüller N, Yıldız M, Sezer C. The role of high mobility group box 1 (HMGB1) in colorectal cancer. Med Sci Monit. 2014; 20:530-37.

2. Toiyama Y, Okugawa Y, Goel A. DNA methylation and microRNA biomarkers for noninvasive detection of gastric and colorectal cancer. Biochem Biophys Res Commun. 2014; 455:43-57.

3. Yu K, Yang J, Jiang Y, Song R, Lu Q. Vitamin D Receptor BsmI Polymorphism and Colorectal Cancer Risk: an Updated Analysis. Asian Pac J Cancer Prev. 2014; 15:4801-4807.

4. de la Chapelle A. Genetic predisposition to colorectal cancer. Nat Rev Cancer. 2004; 4:769-780.

5. Davis CD. Vitamin D and cancer: current dilemmas and future research needs. Am J Clin Nutr. 2008; 88:565S-69S.

6. Kampman E, Slattery ML, Caan B, Potter JD. Calcium, vitamin $\mathrm{D}$, sunshine exposure, dairy products and colon cancer risk (United States). Cancer Causes Control. 2000; 11:459-466.

7. Liu N, Nguyen L, Chun RF, Lagishetty V, Ren S, Wu S, Hollis B, DeLuca HF, Adams JS, Hewison M. Altered endocrine and autocrine metabolism of vitamin
D in a mouse model of gastrointestinal inflammation. Endocrinology. 2008; 149:4799-4808.

8. Pence BC, Buddingh F. Inhibition of dietary fat-promoted colon carcinogenesis in rats by supplemental calcium or vitamin D3. Carcinogenesis. 1988; 9:187-190.

9. Mathew S, Murty VV, Hunziker W, Chaganti RS. Subregional mapping of 13 single-copy genes on the long arm of chromosome 12 by fluorescence in situ hybridization. Genomics. 1992; 14:775-779.

10. Baker AR, McDonnell DP, Hughes M, Crisp TM, Mangelsdorf DJ, Haussler MR, Pike JW, Shine J, O'Malley BW. Cloning and expression of full-length cDNA encoding human vitamin D receptor. Proc Natl Acad Sci U S A. 1988; 85:3294-3298.

11. Vidigal VM, Silva TD, de Oliveira J, Pimenta CAM, Felipe $\mathrm{AV}$, Forones NM. Genetic polymorphisms of vitamin D receptor (VDR), CYP27B1 and CYP24A1 genes and the risk of colorectal cancer. Int J Biol Markers. 2017; 32:e224-e230.

12. Alkhayal KA, Awadalia ZH, Vaali-Mohammed MA, Al Obeed OA, Al Wesaimer A, Halwani R, Zubaidi AM, Khan Z, Abdulla MH. Association of Vitamin D Receptor Gene Polymorphisms with Colorectal Cancer in a Saudi Arabian Population. PLoS One. 2016; 11:e0155236.

13. Takeshige N, Yin G, Ohnaka K, Kono S, Ueki T, Tanaka M, Maehara Y, Okamura T, Ikejiri K, Maekawa T, Yasunami Y, Takenaka K, Ichimiya H, Terasaka R. Associations between Vitamin D Receptor (VDR) Gene Polymorphisms and Colorectal Cancer Risk and Effect Modifications of Dietary Calcium and Vitamin D in a Japanese Population. Asian Pac J Cancer Prev. 2015; 16:2019-2026.

14. Atoum MF, Tchoporyan MN. Association between Circulating Vitamin D, the Taq1 Vitamin D Receptor Gene Polymorphism and Colorectal Cancer Risk among Jordanians. Asian Pac J Cancer Prev. 2014; 15:7337-7341.

15. Laczmanska I, Laczmanski L, Bebenek M, Karpinski P, Czemarmazowicz H, Ramsey D, Milewicz A, Sasiadek MM. Vitamin D receptor gene polymorphisms in relation to the risk of colorectal cancer in the Polish population. Tumour Biol. 2014; 35:12397-12401.

16. Rasool S, Kadla SA, Rasool V, Qazi F, Khan T, Shah NA, Ganai BA. Role of the VDR Bsm I and Apa I polymorphisms in the risk of colorectal cancer in Kashmir. Oncol Res Treat. 2014; 37:345-349.

17. Pibiri F, Kittles RA, Sandler RS, Keku TO, Kupfer SS, Xicola $\mathrm{RM}$, Llor X, Ellis NA. Genetic variation in vitamin D-related genes and risk of colorectal cancer in African Americans. Cancer Causes Control. 2014; 25:561-570.

18. Sarkissyan M, Wu Y, Chen Z, Mishra DK, Sarkissyan S, Giannikopoulos I, Vadgama JV. Vitamin D receptor FokI gene polymorphisms may be associated with colorectal cancer among African American and Hispanic participants. Cancer. 2014; 120:1387-1393.

19. Rasool S, Kadla SA, Khan T, Qazi F, Shah NA, Basu J, Khan BA, Ahktar Q, Sameer AS, Ganai BA. Association of 
a VDR gene polymorphism with risk of colorectal cancer in Kashmir. Asian Pac J Cancer Prev. 2013; 14:5833-5837.

20. Gunduz M, Cacina C, Toptas B, Yaylim-Eraltan I, Tekand Y, Isbir T. Association of vitamin D receptor gene polymorphisms with colon cancer. Genet Test Mol Biomarkers. 2012; 16:1058-1061.

21. Bentley RW, Keown DA, Gearry RB, Cameron VA, Keenan J, Roberts RL, Day AS. Vitamin D receptor polymorphisms in colorectal cancer in New Zealand: an association study. N Z Med J. 2012; 125:47-51.

22. Yamaji T, Iwasaki M, Sasazuki S, Sakamoto H, Yoshida T, Tsugane S. Association between plasma 25-hydroxyvitamin $\mathrm{D}$ and colorectal adenoma according to dietary calcium intake and vitamin D receptor polymorphism. Am J Epidemiol. 2012; 175:236-244.

23. Kupfer SS, Anderson JR, Ludvik AE, Hooker S, Skol A, Kittles RA, Keku TO, Sandler RS, Ruiz-Ponte C, Castellvi-Bel S, Castells A, Carracedo A, Ellis NA. Genetic associations in the vitamin $\mathrm{D}$ receptor and colorectal cancer in African Americans and Caucasians. PLoS One. 2011; 6:e26123.

24. Ashktorab H, Nguza B, Fatemi M, Nouraie M, Smoot DT, Schäffer AA, Kupfer SS, Camargo CA Jr, Brim H. and Brim H. Case-control study of vitamin D, dickkopf homolog 1 (DKK1) gene methylation, VDR gene polymorphism and the risk of colon adenoma in African Americans. PLoS One. 2011; 6:e25314.

25. Abulí A, Fernández-Rozadilla C, Alonso-Espinaco V, Muñoz J, Gonzalo V, Bessa X, González D, Clofent J, Cubiella J, Morillas JD, Rigau J, Latorre M, FernándezBañares F, et al, and Gastrointestinal Oncology Group of the Spanish Gastroenterological Association. Casecontrol study for colorectal cancer genetic susceptibility in EPICOLON: previously identified variants and mucins. BMC Cancer. 2011; 11:339.

26. Mahmoudi T, Karimi K, Mohebbi SR, Fatemi SR, Zali MR. Start codon FokI and intron 8 BsmI variants in the vitamin $\mathrm{D}$ receptor gene and susceptibility to colorectal cancer. $\mathrm{Mol}$ Biol Rep. 2011; 38:4765-4770.

27. Hughes DJ, Hlavata I, Soucek P, Pardini B, Naccarati A, Vodickova L, Jenab M, Vodicka P. Variation in the vitamin $\mathrm{D}$ receptor gene is not associated with risk of colorectal cancer in the Czech Republic. J Gastrointest Cancer. 2011; 42:149-154.

28. Mahmoudi T, Mohebbi SR, Pourhoseingholi MA, Fatemi $\mathrm{SR}$, Zali MR. Vitamin D receptor gene ApaI polymorphism is associated with susceptibility to colorectal cancer. Dig Dis Sci. 2010; 55:2008-2013.

29. Jenab M, McKay J, Bueno-de-Mesquita HB, van Duijnhoven FJ, Ferrari P, Slimani N, Jansen EH, Pischon T, Rinaldi S, Tjonneland A, Olsen A, Overvad K, BoutronRuault MC, et al. Vitamin D receptor and calcium sensing receptor polymorphisms and the risk of colorectal cancer in European populations. Cancer Epidemiol Biomarkers Prev. 2009; 18:2485-2491.
30. Theodoratou E, Farrington SM, Tenesa A, McNeill G, Cetnarskyj R, Barnetson RA, Porteous ME, Dunlop MG, Campbell H. Modification of the inverse association between dietary vitamin $\mathrm{D}$ intake and colorectal cancer risk by a FokI variant supports a chemoprotective action of Vitamin D intake mediated through VDR binding. Int $\mathrm{J}$ Cancer. 2008; 123:2170-2179.

31. Ochs-Balcom HM, Cicek MS, Thompson CL, Tucker TC, Elston RC, J Plummer S, Casey G, Li L. Association of vitamin $\mathrm{D}$ receptor gene variants, adiposity and colon cancer. Carcinogenesis. 2008; 29:1788-1793.

32. Li C, Li Y, Gao LB, Wang YY, Zhou B, Lv ML, Lu HM, Zhang L. Vitamin D receptor gene polymorphisms and the risk of colorectal cancer in a Chinese population. Dig Dis Sci. 2009; 54:634-639.

33. Parisi E, Reñé JM, Cardús A, Valcheva P, Piñol-Felis C, Valdivielso JM, Fernández E. Vitamin D receptor levels in colorectal cancer. Possible role of BsmI polymorphism. J Steroid Biochem Mol Biol. 2008; 111:87-90.

34. Wang G, Li BQ, Zhou HH. Polymorphisms of vitamin D receptor FokI and colorectal cancer risk in Chinese. J Cent South Univ. 2008; 33:339-403.

35. Grünhage F, Jungck M, Lamberti C, Berg C, Becker U, Schulte-Witte H, Plassmann D, Rahner N, Aretz S, Friedrichs N, Buettner R, Sauerbruch T, Lammert F. Association of familial colorectal cancer with variants in the E-cadherin (CDH1) and cyclin D1 (CCND1) genes. Int J Colorectal Dis. 2008; 23:147-54.

36. Flugge J, Krusekopf S, Goldammer M, Osswald E, Terhalle W, Malzahn U, Roots I. Vitamin D receptor haplotypes protect against development of colorectal cancer. Eur J Clin Pharmacol. 2007; 63:997-1005.

37. Slattery ML, Wolff RK, Herrick JS, Caan BJ, Potter JD. IL6 genotypes and colon and rectal cancer. Cancer Causes Control. 2007; 18:1095-1105.

38. Yaylim-Eraltan I, Arzu Ergen H, Arikan S, Okay E, Ozturk $\mathrm{O}$, Bayrak S, Isbir T. Investigation of the VDR gene polymorphisms association with susceptibility to colorectal cancer. Cell Biochem Funct. 2007; 25:731-737.

39. Murtaugh MA, Sweeney C, Ma KN, Potter JD, Caan BJ, Wolff RK, Slattery ML. Vitamin D receptor gene polymorphisms, dietary promotion of insulin resistance, and colon and rectal cancer. Nutr Cancer. 2006; 55:35-43.

40. Kadiyska T, Yakulov T, Kaneva R, Nedin D, Alexandrova A, Gegova A, Savov A, Mitev V, Kremensky I. Vitamin D and estrogen receptor gene polymorphisms and the risk of colorectal cancer in Bulgaria. Int J Colorectal Dis. 2007; 22:395-400.

41. Park K, Woo M, Nam J, Kim JC. Start codon polymorphisms in the vitamin $\mathrm{D}$ receptor and colorectal cancer risk. Cancer Lett. 2006; 237:199-206.

42. Slattery ML, Murtaugh M, Caan B, Ma KN, Wolff R, Samowitz W. Associations between BMI, energy intake, energy expenditure, VDR genotype and colon and rectal cancers (United States). Cancer Causes Control. 2004; 15:863-872. 
43. Peters U, Hayes RB, Chatterjee N, Shao W, Schoen RE, Pinsky P, Hollis BW, McGlynn KA, and Prostate, Lung, Colorectal and Ovarian Cancer Screening Project Team. Circulating vitamin D metabolites, polymorphism in vitamin D receptor, and colorectal adenoma risk. Cancer Epidemiol Biomarkers Prev. 2004; 13:546-552.

44. Boyapati SM, Bostick RM, McGlynn KA, Fina MF, Roufail WM, Geisinger KR, Wargovich M, Coker A, Hebert JR. Calcium, vitamin $\mathrm{D}$, and risk for colorectal adenoma: dependency on vitamin D receptor BsmI polymorphism and nonsteroidal anti-inflammatory drug use? Cancer Epidemiol Biomarkers Prev. 2003; 12:631-637.

45. Wong HL, Seow A, Arakawa K, Lee HP, Yu MC, Ingles SA. Vitamin D receptor start codon polymorphism and colorectal cancer risk: effect modification by dietary calcium and fat in Singapore Chinese. Carcinogenesis. 2003; 24:1091-1095.

46. Peters U, McGlynn KA, Chatterjee N, Gunter E, GarciaClosas M, Rothman N, Sinha R. Vitamin D, calcium, and vitamin D receptor polymorphism in colorectal adenomas. Cancer Epidemiol Biomarkers Prev. 2001; 10:1267-1274.

47. Ingles SA, Wang J, Coetzee GA, Lee ER, Frankl HD, Haile RW. Vitamin D receptor polymorphisms and risk of colorectal adenomas (United States). Cancer Causes Control. 2001; 12:607-614.
48. Kim HS, Newcomb PA, Ulrich CM, Keener CL, Bigler J, Farin FM, Bostick RM, Potter JD. Vitamin D receptor polymorphism and the risk of colorectal adenomas: evidence of interaction with dietary vitamin D and calcium. Cancer Epidemiol Biomarkers Prev. 2001; 10:869-874.

49. Slatter ML, Yakumo K, Hoffman M, Neuhausen S. Variants of the VDR gene and risk of colon cancer (United States). Cancer Causes Control. 2001; 12:359-364.

50. Touvier M, Chan DS, Lau R, Aune D, Vieira R, Greenwood DC, Kampman E, Riboli E, Hercberg S, Norat T. Metaanalyses of vitamin D intake, 25-hydroxyvitamin D status, vitamin D receptor polymorphisms, and colorectal cancer risk. Cancer Epidemiol Biomarkers Prev. 2011; 20:1003-1016.

51. Bai YH, Lu H, Hong D, Lin CC, Yu Z, Chen BC. Vitamin $\mathrm{D}$ receptor gene polymorphisms and colorectal cancer risk: a systematic meta-analysis. World J Gastroenterol. 2012; 18:1672-1679.

52. Olliaro P, Vaillant MT. Alternative visual displays of metaanalysis of malaria treatment trials to facilitate translation of research into policy. Diagn Microbiol Infect Dis. 2010; 68:422-431. 